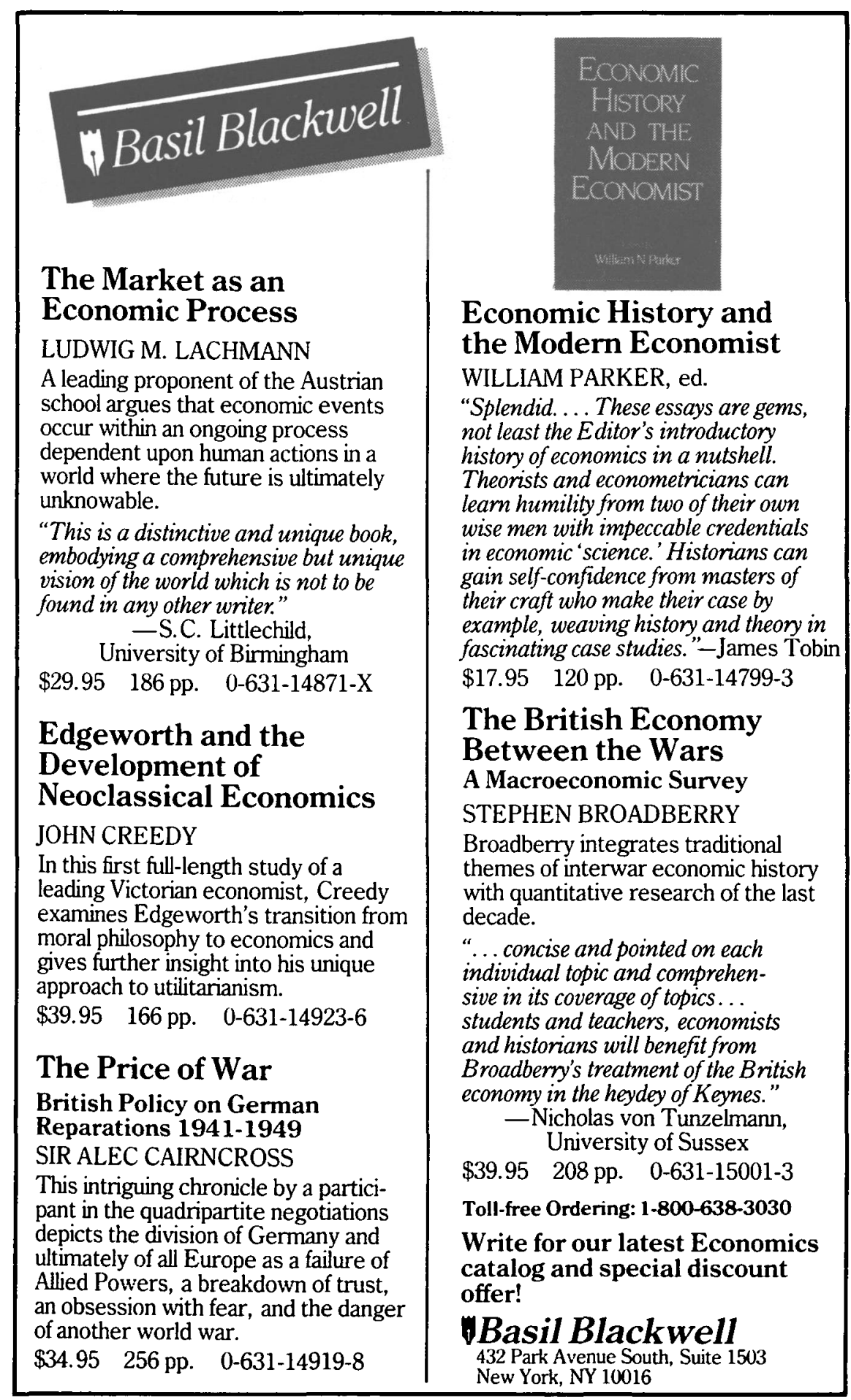




\section{History of Economic Analysis}

\section{The late JOSEPH SCHUMPETER}

At the time of his death in 1950, Joseph Schumpeter-one of the great economists and thinkers of the first half of the 20th century - was working on his monumental History of Economic Analysis. Although never fully completed, it has gained a reputation as a classic of its kind.

Schumpeter was a historian, social scientist, philosopher, psychologist, and mathematician as well as an economist, and the multidisciplinary contents of this book reveal the great scope of his project. Topics discussed include: the techniques of economic analysis, contemporaneous developments in other sciences, and the sociology of economics; economic writings from Plato and Aristotle up through the time of Adam Smith, including the medieval scholastics and natural-law philosophers; the work of Malthus, Mill, Ricardo, Marx, and the important European economists; the history, sociology, psychology, and economics of the period from 1879 to 1914 ; and modern developments in economics.

October 1986 1,288 pp. paper \$19.95

Price and publication date are subject to change.

To request an examination copy, write on school letterhead giving full course information, including course name, level, expected enrollment, and your decision deadline, to: College Humanities \& Social Sciences Marketing Dept.

\section{Oxford University Press}

200 Madison Avenue $\cdot$ New York, NY 10016

\section{THE ARTHUR H. COLE GRANTS-IN-AID}

\section{For Research in Economic History}

- are awarded each year to supplement other sources of research support;

- are biased in favor of young post-doctorates turning dissertations into publishable articles and monographs, but are open to all;

- are awarded by the six-member Committee on Research in Economic History on the basis of an application due on April 1 each year;

- are granted for research in any geographic region in the world and in any time period;

- are described in more detail in a prospectus sent out by the Secretary, Council on Research in Economic History, The Economic History Association, Box 3630, Wilmington, Delaware 19807. 
New in cloth and paper

\section{Economic Growth in the Third World: An Introduction}

\section{Lloyd G. Reynolds}

The first comprehensive overview of third world economic growth, derived from Reynolds's larger Economic Growth in the Third World, 1850-1980 and now available in a compact, inexpensive volume. "For anybody with an informed interest in economic history, it is a stimulating work that is recommended reading." - Bruce Luckman, Africa Economic Digest $\$ 24.00$ cloth; $\$ 7.95$ paper

A Publication of the Economic Growth Center

\section{Social Change and the Labouring Poor} Antwerp, 1770-1860

\section{Catharina Lis}

The first thorough study of social dislocation in a major European city during the Industrial Revolution. Lis analyzes the processes that caused the growth of a large, segregated, impoverished urban proletariat and reveals that pauperization was not mitigated by industrial growth or modernization, but represented an endemic feature of the capitalist economy. $\$ 20.00$

\section{In Whose Interest?}

International Banking and American Foreign Policy

Benjamin J. Cohen

The first book to investigate the potential for conflict between the interests of American banks and the goals of American foreign policy. Cohen illustrates his study with case histories of how American foreign policy has been affected by the growth of Arab deposits in American banks, by the freezing of Iranian assets during the hostage crisis, and by Polish and Latin American debts to Western banks. $\$ 19.95$ A Council on Foreign Relations Book
Leadership at the Fed

\section{Donald F. Kettl}

A colorful and fascinating history of one of Washington's most powerful agencies and of the men who enabled it to grow into the national and international force it is today. Making use of extensive interviews, documents uncovered at all of the nation's presi. dential libraries, and other sources never before researched, Kettl provides a unique look at the leaders of the Federal Reserve Board, from Marriner Eccles to G. William Miller to Paul_ Volcker. $\$ 27.50$

\section{Stabilizing an Unstable Economy}

Hyman P. Minsky

A senior economist provides a pathbreaking financial theory of investment to explain the unstable behavior of the American economy and offers recommendations for stabilizing it at high employment while maintaining a steady price level.

"Brilliant." - Robert Lekachman $\$ 29.95$

A Twentieth Century Fund Report

\section{Journal of Law, Economics, and Organization}

Jerry Mashaw and Oliver Williamson, co-editors One-year subscription (two issues): $\$ 28.00$ institutions, $\$ 20.00$ individuals

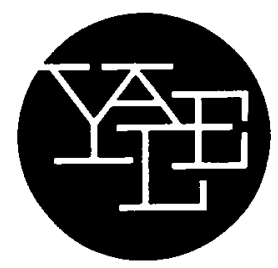

Yale University Press Dept. 309 $92 \mathrm{~A}$ Yale Station New Haven, CT 06520 


\section{NOW AVAILABLE... \\ THE FINAL FOUR VOLUMES IN A MONUMENTAL SERIES}

\section{The Collected Works of Walter Bagehot}

\section{Edited by Norman St. John-Stevas}

Walter Bagehot, banker, economist, political thinker, and commentator, critic, man of letters, and inventor of the Treasury Bill, was arguably Victorian England's most versatile genius. Under the auspices of The Economist, Norman St. John-Stevas has over the last twenty years assembled and edited the body of Bagehot's prodigious writings. The publication of the last four volumes of Walter Bagehot's writings - the Letters and Miscellany - is the finale to the first eleven volumes of his collected literary, historical, political and economic essays. It is an historic event, one that completes the picture of the man who has been described as "the greatest mind of his generation."

\section{Volumes XII and XIII: Letters}

Meticulously established, dated and annotated, these letters offer glimpses of Bagehot at different stages of his life.

\section{Volumes XIV and XV: Miscellany}

These collected essays present Bagehot's thoughts on a broad spectrum of subjects, as well as conversations, reminiscences by friends, a family tree and two bibliographies.

Norman St. John-Stevas, author of Walter Bagehot: A Study of Life and Thought, was for five years the political correspondent of The Economist. He has held a number of political offices and is currently Chairman of the Royal Fine Arts Commission.

$\$ 135.00$ for boxed sets $\$ 750.00$ for the complete set

Full descriptive brochure available upon request.

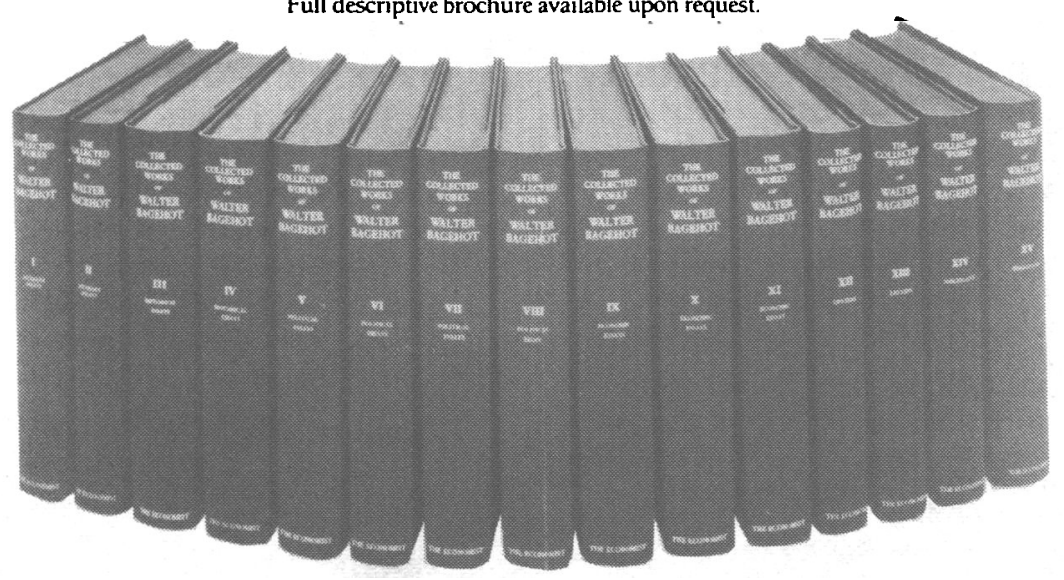




\section{Cantillon}

Entrepreneur and Economist

ANTOIN MURPHY, Trinity College, Dublin

This is a study of Richard Cantillon, the 18th-century banker, economist, and author of the influential Essai sur la Nature du Commerce en General (1755). Cantillon was involved in high-level international banking and speculation in foreign exchange, commodities, and stocks at the time of the South Sea Bubble.

$1986 \quad 272$ pp. $\$ 38.00$

\section{The Correspondence of Adam Smith}

\section{Second Edition}

Edited by ERNEST CAMPBELL MOSSNER, formerly of the University of Texas at Austin, and IAN SIMPSON ROSS, University of British Columbia This new edition incorporates eighteen entirely new letters that have been discovered since 1977.

(The Glasgow Edition of the Works and Correspondence of Adam Smith) October 1986496 pp. $\$ 65.00$

\section{Poland, the United States, and the Stabilization of Europe, 1919-1933}

NEAL PEASE, University of Wisconsin

The first full-length study of relations between Poland and the U.S. following World War I, this book lucidly examines how Polish leaders of the $1920 \mathrm{~s}$ sought to enlist U.S. political and financial support on behalf of their beleaguered state. It reveals how Poland had to counter American isolationism as well as America's reluctance to underwrite a nation surrounded by two strong and hostile neighbors, Germany and the Soviet Union.

1986224 pp. $\$ 24.95$

\section{Town and Country Under Fascism}

The Transformation of Brescia 1915-1926

ALICE A. KELIKLAN, Brandeis University

Tracing the origins of fascism in Brescia, one of Italy's key manufacturing centers, this book offers a dramatic example of the commercial and social diversity which slowed the establishment of dictatorship in the country as a whole.

1986300 pp.; 2 maps $\$ 42.00$

\section{Culture and Society in Britain 1850-1890}

A Source Book of Contemporary Writings

Edited by J.M. GOLBY, The Open University

This volume reflects people's concerns that materialized in the face of 19 th-century Britain's rapid scientific, technological, and social change, and traces the profound transformations that took place in culture and society during this eventful period.

December 1986320 pp.; 10 illus. cloth $\$ 24.95$; paper $\$ 8.95$

Prices and publication dates are subject to change.

To order, send check or money order to: Humanities E Social Sciences Marketing Dept.

\section{Oxford University Press}


"This is no mere reference book but one to read with infinite pleasure... marvellously representative of more than a century of British industry and commerce."

Business Review

\section{The Dictionary of Business Biography}

Editor: David J Jeremy, BA, MLitt, PhD, FRHists, Research Fellow, Business History Unit, London School of Economics, Deputy editor: Christine Shaw, MA, DPhil, Research Officer, Business History Unit, London School of Economics

The Dictionary of Business Biography contains over 1,000 biographies and sets out to rectify our lack of knowledge about British businessmen and their achievements between 1860 and 1980. Each of the contributed biographies gives a complete description of its subject and goes on to examine their business career in detail. Notable successes and failures, major innovations, individual management styles and policies, outside business interests and political activities are all described and assessed in the context of a business's rise or fall. Each entry is illustrated and concludes with a bibliography of the subject's writings and reported speeches and a list of sources used in preparing the entry.

"The physical presentation is excellent: good layout, clear typeface, sharp reduction of the portraits and illustrations... it is definitely worth the cost for those who can make use of such a valuable reference tool: large university and public libraries, historical research centres, and certain business libraries as well. It is highly recommended."

\section{American Reference Books Annual}

Published in five hard cover volumes at $\$ 795.00$ for the set or $\$ 185.00$ per volume.

For further details of the Dictionary of Business Biography, please write to:

The Marketing Department, Butterworth (Publishers) Inc. 80 Montvale Avenue, Stoneham, Mass. 02180.

Tel: $[617) 4388464$

\section{Butterworths}




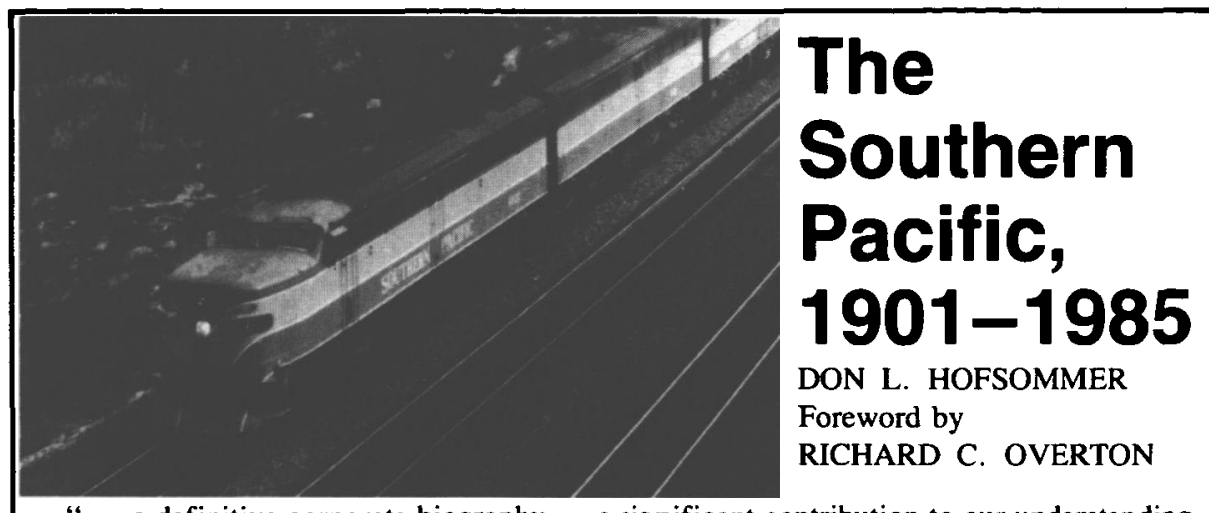

". . . a definitive corporate biography. . . a significant contribution to our understanding of the history of the West and Southwest."-Keith L. Bryant. " . . offers fresh, revealing insights into the twentieth-century strategies and operations of one of the nation's great railroads."-H. Roger Grant.

With unrestricted access to Southern Pacific's files and entrée to corporate officers and employees, Don L. Hofsommer has written the first comprehensive history of the transportation colossus in the twentieth century. He evaluates successive management teams; compares SP's performance with that of its premier competitors; analyzes its decision to diversify; and interprets the company's story in the context of regional and national patterns and of the service area influenced so greatly. 412 pp. 9 color, 200 b\&w illus. 24 maps. $\$ 44.50$

\section{But Also Good Business}

Texas Commerce Banks and the Financing of

Houston and Texas, 1886-1986

WALTER L. BUENGER

JOSEPH A. PRATT

The history of Texas Commerce Bank, one of the state's largest, is the story of the growth of the region's lumber, cotton, and oil industries. The major focus of the book is the bank's changing position in the flow of credit into the regional economy. Thus the authors provide a perspective on the financing of economic development seldom included in the literature on banking history. Other major themes include the historical relationship of Houston banks to the much larger money center banks in New York and Chicago. 442 pp. Illus. $\$ 29.50$

\section{Prime Cut}

\section{Livestock Raising and Meatpacking in the United States, 1607-1983 JIMMY M. SKAGGS}

Jimmy Skaggs traces the development of this uniquely American industry from the forest-foraging razorbacks of colonial days to present-day genetic engineering of tender, disease-resistant beef cattle. Detailed examinations of seventeenth-century slaughterhouses, the cattle barons of the Great Plains, the birth of conglomerates, the outcry incited by Upton Sinclair's The Jungle, the groundswell of organized labor, modern-day inspections, and foreign competition provide a history of American business that begins in national innocence and ends, for now, with a cautious look at the success of reforms. $270 \mathrm{pp}$. Illus. $\$ 28.50$

TEXAS A\&M UNIVERSITY PRESS • College Station, Texas 77843 


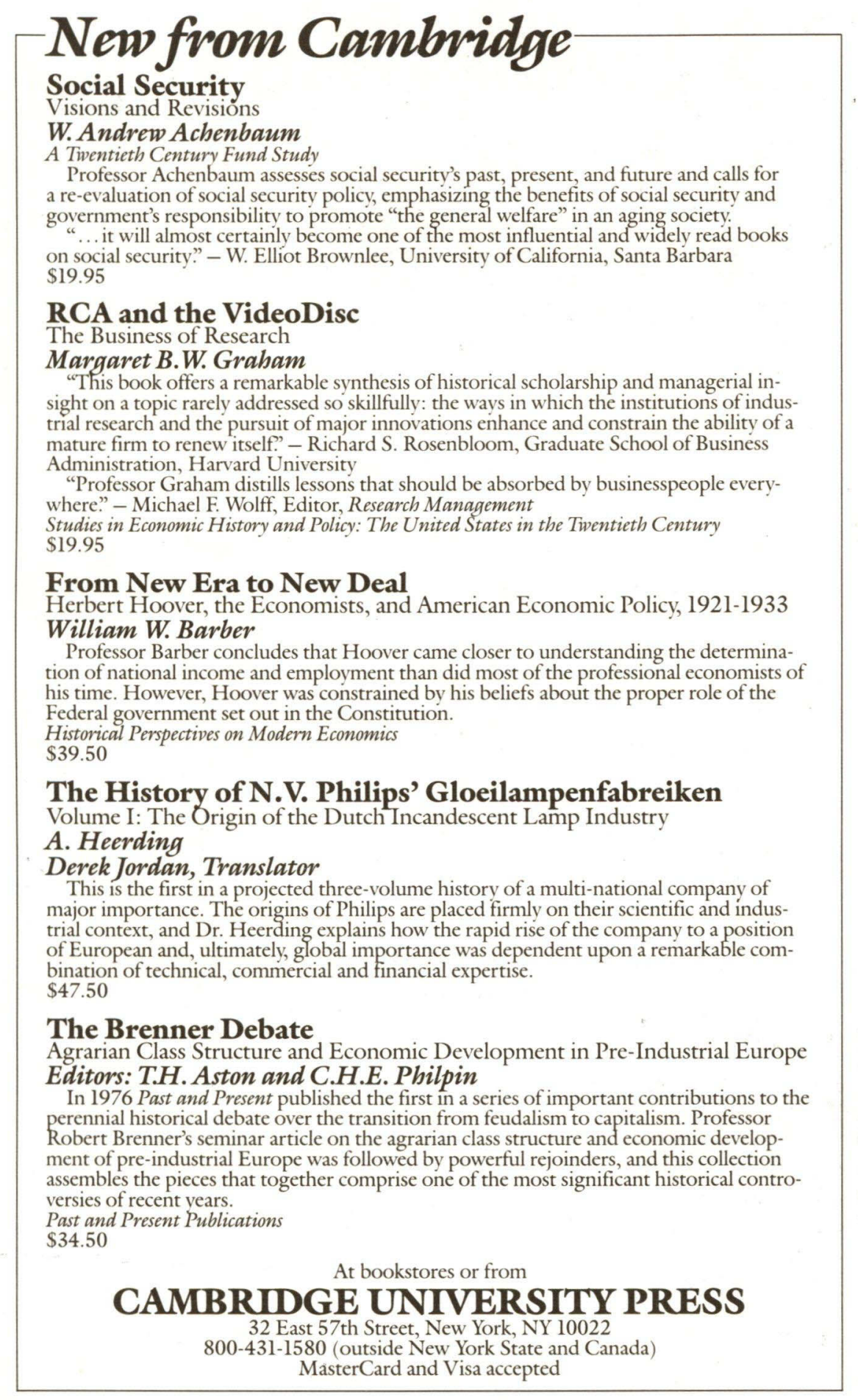

